\title{
ADHERENCE AND PATHOGENICITY ASSAY OF VIBRIO HARVEYI IN TIGER SHRIMP (PENAEUS MONODON) LARVAE FOR SCREENING BIOCONTROL AGENT
}

\author{
YUSMINAH HALA ${ }^{1}$, ANTONIUS SUWANTO ${ }^{23}$, RIDWAN AFFANDI $^{4}$ and \\ MUHAMMAD ZAIRIN Jr. ${ }^{4}$
}

\author{
'Department of Biology, Faculty of Science and Mathematics, Makassar University, \\ Makassar 90221, Indonesia ${ }^{2}$ Department of Biology, Faculty \\ of Science and Mathematics, Bogor Agricultural \\ University, Bogor, Indonesia \\ ${ }^{J}$ SEAMEO-BIOTROP, Jl. Raya Tajur Km 6, Bogor, Indonesia \\ ${ }^{4}$ Department of Aquaculture, Faculty of Fisheries and Marine Science, Bogor Agricultural \\ University, Bogor 16680, Indonesia
}

\begin{abstract}
Rifampicin-resistant marker was employed as a reporter to detect the adherence and colonization of $V$. harveyi in shrimp larvae. Vibrio harveyi P1B and YA32.2 were isolated from dead shrimp larvae in Besuki, Northern Coast of East Java, while V. harveyi HB3, was isolated from pristine sea water in Pacitan, Southern Coast of East Java. Vibrio metschnikovii used as biocontrol agent was isolated from healthy shrimp larvae in Serang, West Java. Spontaneous mutation was conducted to generate $V$. harveyi P1B, YA32.2 and HB3 resistant to rifampicin. These mutants exhibited similar survival ability to their parental (wild type) strains. Significant larval mortality was observed in shrimp larvae inoculated with YA32.2 than that of larvae inoculated with P1B. Larvae inoculated with HB3 showed the lowest mortality. Bacterial cell count of Vibrio Rf* in dead larvae were $10^{3}-10^{4}$ cells/larvae. Isolates of Vibrio metschnikovii $\mathrm{Z}$ and $\mathrm{M}$ as biocontrol candidates effectively reduced the growth and adherence ability of YA32.2 to shrimp larvae. Larval mortality in rearing water inoculated simultaneously with YA32.2 and $V$. metschnikovii was lower than the one inoculated with YA32.2 alone. Therefore, Vibrio metschnikovii Z or M could be developed as an effective probiotic or biocontrol agent for $V$. harveyi in shrimp hatcheries.
\end{abstract}

Key words : Biological control/Vibrio metschnikovii/shrimp larvae/Penaeus mwu«fon/pathogenicity assay/Vibrio harveyi

\section{INTRODUCTION}

Shrimp farming is one of the most important activities in Indonesia and other Asian countries such as Thailand, Phillippines, and India (Ruangpan 1998). Up to 1997, Indonesia was the second largest world producer of tiger shrimp (Penaeus monodori) after Thailand with a production of more than 99000 metric tons of tiger shrimp (Anonymous 1999). However, the exponential growth of shrimp culture in the last five years was not supported properly by a sufficient supply of shrimp larvae

*Corresponding author : e-mail address : asuwanto@indo.net.id: Fax : 62-251-315107 38 
BIOTROPIA NO. 18, 2002

due to larval diseases and poor environmental quality of the hatcheries. Among shrimp diseases, vibriosis is one of fatal bacterial diseases. This disease is caused by Vibrio sp. that attacks the tiger shrimp at early larval or post-larval stage.

Mass mortality of shrimp larvae frequently associated with luminous Vibrio (Lavilla-Pitogo et al. 1998; Sunaryanto \& Mariam 1986) was identified as Vibrio harveyi (Karunasagar et al. 1994; Lavilla-Pitogo et al. 1990). Although Vibrio carchariae was reported as a pathogen in a brown shark (Carcharinus plumbeus) that was found dead in captivity (Grimes et al. 1984), it has not been reported as a pathogen of shrimp larvae. It was also found associated with a chronic skin ulcer on a shark (Bertone et al. 1996).

So far, it has not been determined whether luminous Vibrio is a pathogen or saprophyte, even though it could frequently be isolated from dead larvae. Therefore, the pathogenicity status of this group of bacteria is uncertain. Pathogenicity assays based on Koch's Postulate (Salyers \& Whitt 1994) is practically difficult to be conducted in tiger shrimp larvae due to its relatively small size and since so far, no germ-free larvae are available (Hameed 1993). The source of luminous Vibrio colonized shrimp larvae might originate from the midgut contents of the spawners (Lavilla-Pitogo et al 1992).

Bacterial pathogenicity is determined by several factors such as the ability to adhere to the host tissue to colonize and to secrete virulence factors (Salmond et al. 1995). The aim of this study was to determine the adherence and colonization of Vibrio isolates and their pathogenicity to shrimp larvae. Bacterial isolates were molecularly tagged to distinguish it from Vibrio naturally associated with the shrimp larvae. Luminous Vibrio isolated from hatcheries and coastal water in East Java, Indonesia, showed sensitivity to rifampicin (Tjahyadi et al. 1994). Therefore, we used rifampicin resistant $\left(\mathrm{Ri}^{*}\right)$ Vibrio generated by spontaneus mutation as a marker for $V$. harveyi isolates used in this study. Vibrio harveyi P1B and YA32.2 were isolated from dead larvae, while HB3 was isolated from pristine sea water (Suwanto et al. 1998; Teo et al. 2000). Our study also indicates that adherence assay in this study could be developed to screen for potential biocontrol bacteria or probiotics against pathogenic Vibrio.

\section{MATERIALS AND METHOD}

\section{Isolation and Identification of Vibrio carchariae}

The dead shrimp larvae were obtained in February 1997 from Besuki in the Northern Coast of East Java, Indonesia. The larvae were rinsed twice with sterile sea water and placed aseptically on the thiosulphate citrate bile salt (TCBS) agar. The plate was incubated for $24 \mathrm{~h}$ at room temperature $\left(28 \pm 2{ }^{\circ} \mathrm{C}\right)$. Isolated luminous colonies were restreaked'on Vibrio harveyi agar (VHA) (Harris et al. 1996). 
Bacterial characterization was conducted employing cellular fatty acid analyses by Microcheck, Inc., Microbial Analyses Laboratory in Northfield, USA. Bacteria were grown on trypticase soy broth agar (TSBA) at $28{ }^{\circ} \mathrm{C}$ and then extracted for cellular fatty acid analysis (Miller 1982). The fatty acid composition of each isolate was compared to a database of standard strain (V. carchariae ATCC 35084) profile, using overlap coefficient which allows their identification according to their similarity index.

Two other $V$. harveyi isolates used in this study were isolated and characterized from dead larvae (P1B) and from pristine sea water (HB3) (Suwanto et al. 1998).

\section{Antibiotics Sensitivity}

In order to tag Vibrio with the antibiotics resistant markers, it is necessary to determine the natural antibiotic sensitivity of the isolates. All isolates used in this research were tested for antibiotic sensitivity against kanamicin (50 p.g/ml), ampicillin (50 $\mathrm{lo.g} / \mathrm{ml})$, tetracycline (10 $\mathrm{J.g} / \mathrm{ml})$, gentamicin $(20 \mathrm{ng} / \mathrm{ml})$ and rifampicin (10 jj.g/ml) on Luria Bertani (LB) agar (10 g Nad, $10 \mathrm{~g}$ tryptone, 0.5 g yeast extract, $15 \mathrm{~g}$ agar and $1 \mathrm{~L}$ distilled water).

\section{Rifampicin-Resistant Vibrio harveyi}

Spontaneous mutants of $V$. harveyi resistant to rifampicin (Rf*) were selected on LB agar supplemented with rifampicin (50 (ig/ml) (Eisenstad et al. 1994). The survival of Rf* $V$. harveyi was evaluated and compared to the wild type strains in artificial larval-rearing water $(3 \% \mathrm{NaCl}$ and $0.3 \%$ yeast extract in $1 \mathrm{~L}$ distilled water $=$ SYE).

\section{Growth Pattern and Survival Assay}

Vibrio harveyi Rf" was inoculated into $100 \mathrm{ml}$ SYE media and incubated at $28^{\circ} \mathrm{C}$. Cell concentration was enumerated daily on TCBS and TCBS supplemented with 50 (J.g/ml Rf (TCBS-Rif). Enumeration began just after $V$. harveyi was inoculated into SYE media. The survival of $V$. harveyi on TCBS was compared with the survival on TCBS-Rif to detect the stability of the Rf* mutation.

\section{Preparation of Shrimp Larvae}

Two-day-old tiger shrimp postlarvae (PL2) and sea water for larval rearing were obtained from a hatchery in Labuhan, West Java. The larvae were maintained for acclimatization in a three-liter glass stock jar for at least two days in laboratory condition. Sea water salinity was maintained at $2.5 \%$ and at a temperature of 28 $30^{\circ} \mathrm{C}$. The larvae were fed on an artificial diet (Lanzy $P L$; Inve aquaculture, Belgium). For adherence and pathogenicity assays, 50 larvae were kept in a threeliter glass jar containing 2.5 liters of autoclave-sterilized sea water. 


\section{Adherence Assay}

Tested bacterial strains used in the adherence assays were cultured in $50 \%$ sea water complex (SWC) agar medium ( $\mathrm{pH} 7.2$ ) for $24 \mathrm{~h}$ at $28{ }^{\circ} \mathrm{C}$. The culture was harvested by adding $5 \mathrm{ml}$ sterile sea water onto the bacterial lawn, scraped, and collected into a tube, and then centrifuged at $5000 \mathrm{x}$ g for two minutes. The bacterial cells were rinsed in sterile sea water and diluted to give a final concentration of $10^{6}$ $\mathrm{CFU} / \mathrm{ml}$. The number of wild type Vibrio and Vibrio Rf* in larval rearing water was enumerated daily on TCBS and TCBS-Rif, respectively. The number of larval mortality was counted daily. The Vibrio harveyi which colonized the dead larvae was enumerated daily on TCBS-Rif.

\section{Challenge Test}

The isolates used for the challenge test in this study were Vibrio metschnikovii isolates $\mathrm{Z}$ and $\mathrm{M}$, which were isolated from healthy zoea (Z) and mysis (M), respectively (Widanarni 1999). Cell suspension of Vibrio metschnikovii $\mathrm{Z}$ and $\mathrm{M}$ at a concentration of $10^{8} \mathrm{CFU} / \mathrm{ml}$ were inoculated into larval rearing jar $2 \mathrm{~h}$ before the shrimp larvae were introduced into the jar. After $6 \mathrm{~h}$ cocultivation of $\mathrm{Z}$ or $\mathrm{M}$ isolate with shrimp larvae, pathogenic Vibrio (YA32.2 Rf*) were inoculated into the larval rearing jar. The treatments consisted of YA32.2 Rf" which was challenged with $V$. metschnikovii Z, M, or a combination of $\mathrm{Z}$ and $\mathrm{M}$. Shrimp larvae cocultivated with YA32.2 Rr* alone was employed as a control. The number of larval mortality as well as concentration of wild type Vibrio and Vibrio Rf* in the dead larvae and in rearing water were enumerated daily after cocultivation. The total number of Vibrio was enumerated on TCBS agar, while Vibrio $\mathrm{Rf}^{\mathrm{R}}$ was counted on TCBS-Rif. Each experiment was conducted in duplicates. The number of dead larvae and bacterial cell concentration were presented in average values.

\section{RESULTS}

\section{Isolation and Identification of Vibrio carchariae}

Two Vibrio isolates (YA32.2 and YA31.4) were isolated from dead larvae. Colonies of these isolates were luminous, circular and appeared green with dark green in the center of the colony when grown on TCBS agar. They also grew on VHA, a differential agar for Vibrio harveyi (Harris et al. 1996), and appeared as blue colonies due to decarboxylation of ornithin which shifted $\mathrm{pH}$ medium toward alkaline. When illuminated from below, yellow halos appeared, indicating cellobiose fermentation around the colonies. Based on these specific characteristics, YA32.2 and YA31.4 were identified as $V$. harveyi. 
Cellular fatty acid analyses of YA32.2 and YA31.4 grown on trypticase soybroth agar indicated that similarity index to V. carchariae ATCC 35084 were 0.955 and 0.944 , respectively. These similarity indices were much higher than those of $V$. parahaemolyticus or $V$. alginolyticus (Table 1). However Bergey's Manual classifies $V$. carchariae as a junior synonym (variant) to $V$. harveyi (Baumann et al. 1994).

Four Vibrio harveyi isolates used in this study, i.e.: P1B, HB3, YA32.2 and YA31.2, were resistant to ampicillin (50 tig/ml) and kanamicin (50 Jig/ml) but sensitive to tetracycline $\left(10^{\prime} \mid \mathrm{ig} / \mathrm{ml}\right)$, gentamicin $(20(\mathrm{~J}-\mathrm{g} / \mathrm{ml})$ and rifampicin $(10(\mathrm{~J} . \mathrm{g} / \mathrm{ml})$ (Tabel 2).

\section{Vibrio harveyi Mutant $\mathrm{Rf}^{11}$}

An amount of 50-100 u.1 of $10^{8} \mathrm{CFU} / \mathrm{ml} V$. harveyi was inoculated onto LB agar supplemented with $50(\mathrm{~J}-\mathrm{g} / \mathrm{ml}$ rifampicin. Isolated colony which showed similar morphology and luminescence to the wild type was further employed for survival assay. The growth pattern and survival of three mutants P1B Rf*, YA32.2 Rt* and HB3 Rf* were similar to their parental wild type strains (data not shown).

Table 1. Similarity index isolates YA32.2 and YA31.4 with Vibrio sp based on cellular fatty acid profiles

\begin{tabular}{ccc}
\hline \hline Vibrio sp & YA32.2 & YA31.4 \\
\hline Vibrio & 0.955 & 0.944 \\
V. carchariae & 0.955 & 0.944 \\
V. parahaemolyticus & 0.928 & 0.921 \\
V.p. sub group B & 0.928 & 0.921 \\
V.p sub group A & 0.775 & 0.807 \\
V.alginoliticus & 0.892 & 0.888 \\
V.a. sub group A & 0.892 & 0.888 \\
V.a. sub group B & 0.774 & 0.812 \\
Listonella & 0.880 & 0.887 \\
L. anguillarum) & 0.880 & 0.887 \\
Photobacterium & 0.533 & 0.660 \\
P. damsela & 0.533 & 0.660 \\
P. leiognathi & 0.315 & 0.378 \\
\hline
\end{tabular}

Remarks : Analyses were conducted by Microcheck, Inc. Microbial Analysis Laboratory Northfield, New Hampshire 
BIOTROPIA NO. 18, 2002

Table 2. Inhibition zone of antibiotics to the growth of four Vibrio harveyi isolates used

\begin{tabular}{|c|c|c|c|c|}
\hline \multirow{2}{*}{$\begin{array}{l}\text { Antibiotics } \\
\text { Concentration } \\
(\cdot \mathrm{g} / \mathrm{ml})\end{array}$} & \multicolumn{4}{|c|}{ Inhibiton zone (mm) } \\
\hline & PIB & HB3 & YA32.2 & YA31.4 \\
\hline Ampicillin & . & & & \\
\hline 25 & 0 & 0 & 0 & 0 \\
\hline 50 & 0 & 0 & 0 & 0 \\
\hline 100 & 1 & 0 & 1 & 2 \\
\hline \multicolumn{5}{|l|}{ Kanamicin } \\
\hline 25 & 0 & 0 & 0 & 0 \\
\hline 50 & 0 & 0 & 0 & 0 \\
\hline 100 & 1 & 1 & 1 & 0 \\
\hline \multicolumn{5}{|l|}{ Tetracycline } \\
\hline 5 & 0 & 0 & 0 & 0 \\
\hline 10 & 2 & 3 & 2 & 2 \\
\hline 20 & 2 & 3 & 3 & 3 \\
\hline \multicolumn{5}{|l|}{ Gentamicin } \\
\hline 10 & 0 & 0 & 0 & 0 \\
\hline 20 & 2 & 2 & 1 & 2 \\
\hline 25 & 2 & 3 & 2 & 2 \\
\hline \multicolumn{5}{|l|}{ Rifampicin } \\
\hline 10 & 1 & 2 & 1 & 1 \\
\hline 20 & 2 & 2 & 2 & 2 \\
\hline 25 & 2 & 3 & 2 & 3 \\
\hline
\end{tabular}

\section{Adherence Assay}

About $10^{6} \mathrm{CFU} / \mathrm{ml}$ of $V$. harveyi Rf* was inoculated into larval rearing water for adherence assay on shrimp larvae. Bacterial growth profile in larval rearing water showed similar patterns to that of the wild type (Fig. 1). The three strains showed bacterial growth patterns that generally increased in cell concentration at first to second or third day and decreased the following days. The highest concentration of Vibrio $\mathrm{Ri}^{*}$ in larval-rearing water was approximately $10^{7} \mathrm{CFU} / \mathrm{ml}$.

Larval mortality in response to the three Vibrio $\mathrm{Rf}^{*}$ strains was different as presented in Figure 2. Isolate YA32.2 caused the highest larval mortality on the first day and the number of Vibrio $\mathrm{Rf}^{*}$ found in the dead larvae was $2.3 \times 10^{3} \mathrm{CFU} / \mathrm{larvae}$. On the second day after inoculation, the number of dead larvae increased to 36 animals concomitant with the highest Vibrio Rf* concentration at $1.2 \times 10^{4} \mathrm{CPU} /$ larvae. All of the larvae were found dead on the third day with Vibrio Rf" found in the larvae at concentration of $1.3 \times 10^{4} \mathrm{CFU} /$ larvae . 
Adherence and pathogenecity assay of Vibrio harveyi - Yusminah Hala et al.
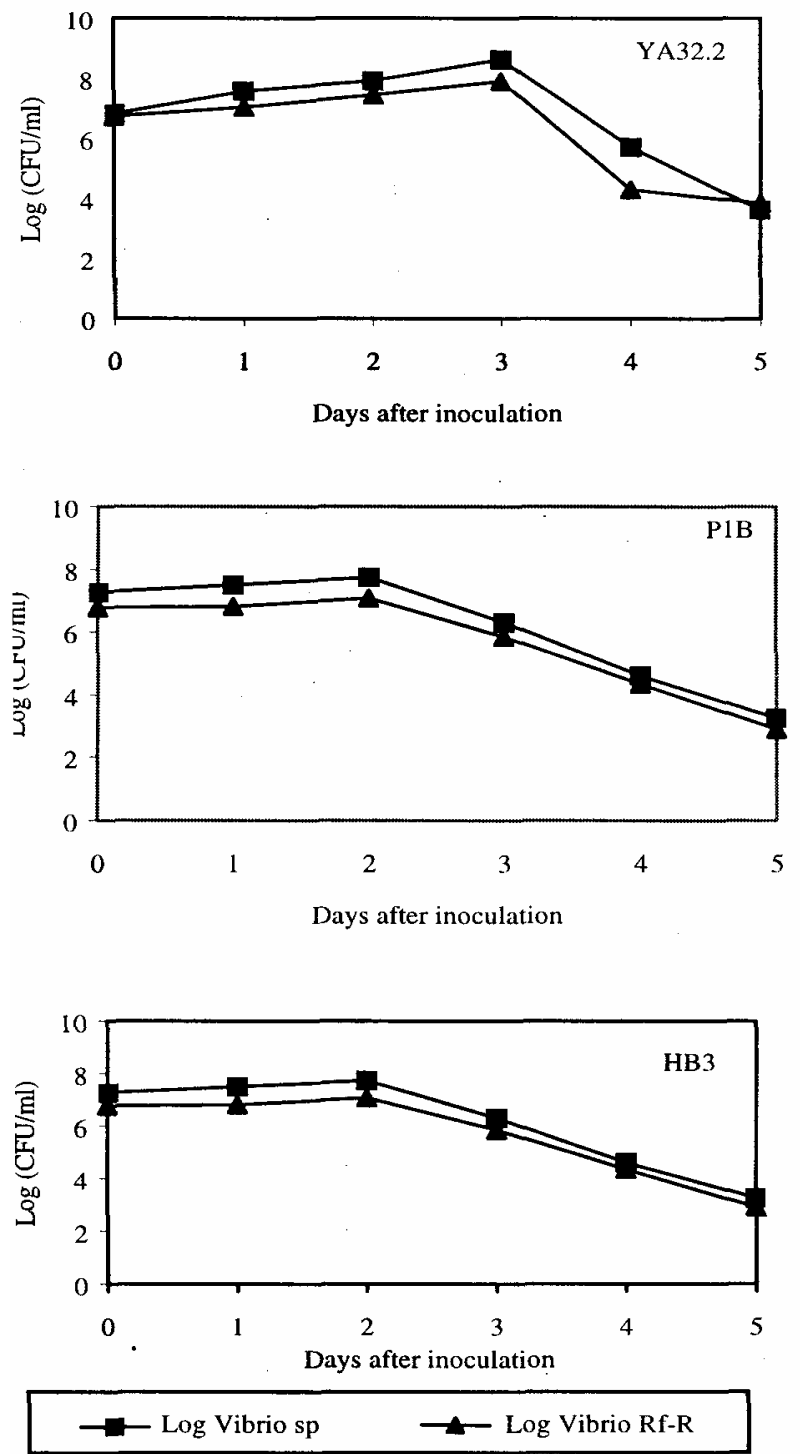

Figure 1. Comparison of Vibrio $\mathrm{RF}^{*}$ and their respective parental wild type growth pattern in the larval rearing water 
BIOTROPIA NO. 18, 2002
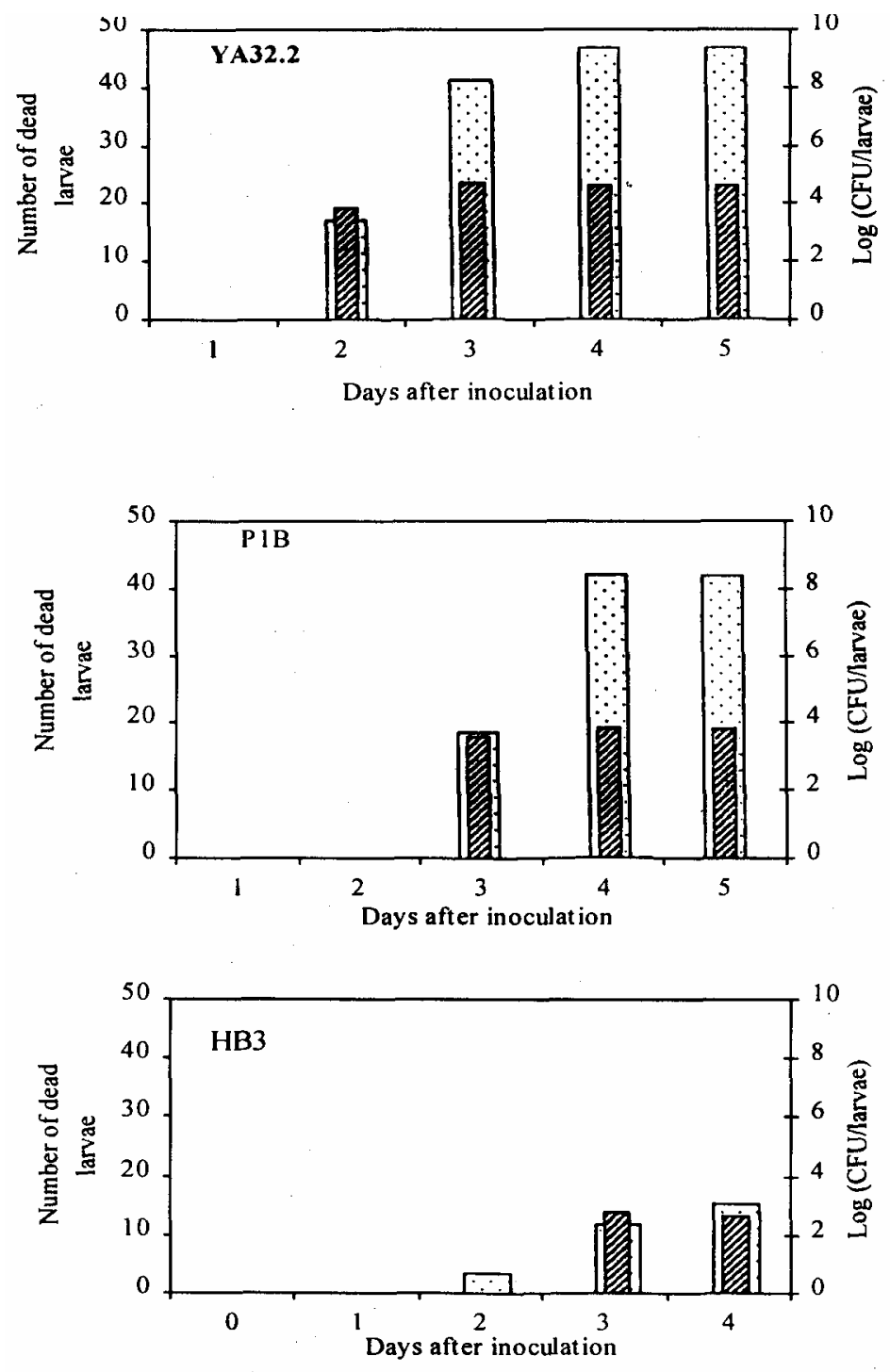

$\square$ Dead larvae

vibrio Rf-R

Figure 2. Correlation between the cumulative number of death larvae and the number of Vibrio adhered in the shrimp larvae 
Larval mortality in the jars inoculated with P1B occured on the second day after inoculation. The number of dead larvae found on the second day was 19 animals. Larval mortality reached its highest number on the third day when the concentration of Vibrio Rf* in the larvae was $8.7 \mathrm{xlO}^{\mathrm{J}} \mathrm{CFU} / \mathrm{larva}$. The lowest larval mortality was found in the larvae inoculated with HB3: Larval mortality was found only after three days of coinoculation, and until the last day of observation, larval mortality occurred in only 13 animals carrying Vibrio Rf* at concentration of 1.75xl0² CFU/larva (Fig. 3).

\section{Challenge Test}

Shrimp larvae inoculated with YA32.2 supplemented with $V$. metschnikovii Z or $\mathrm{M}$, either alone or in combination, showed less mortality than the larvae treated only with YA32.2 alone as shown in Figure 4. The number of dead larvae when treated with YA32.2 in the presence of $V$. metschnikovii M was 11 larvae. Moreover, the number of dead larvae slightly increased if YA32.2 was inoculated in the presence of $\mathrm{Z}$ and $\mathrm{M}$, although the number of Vibrio $\mathrm{Rf}^{*}$ which adhered to the larvae was relatively similar i.e. $1.2 \times 10^{2}$ to $3.2 \times 10^{2}$ CFU/larva. All of the larvae treated with YA32.2 were found dead after three days of cocultivation when concentration of Vibrio Rf* in the larvae reached $10^{4}$ CFU/larva (Fig.4).

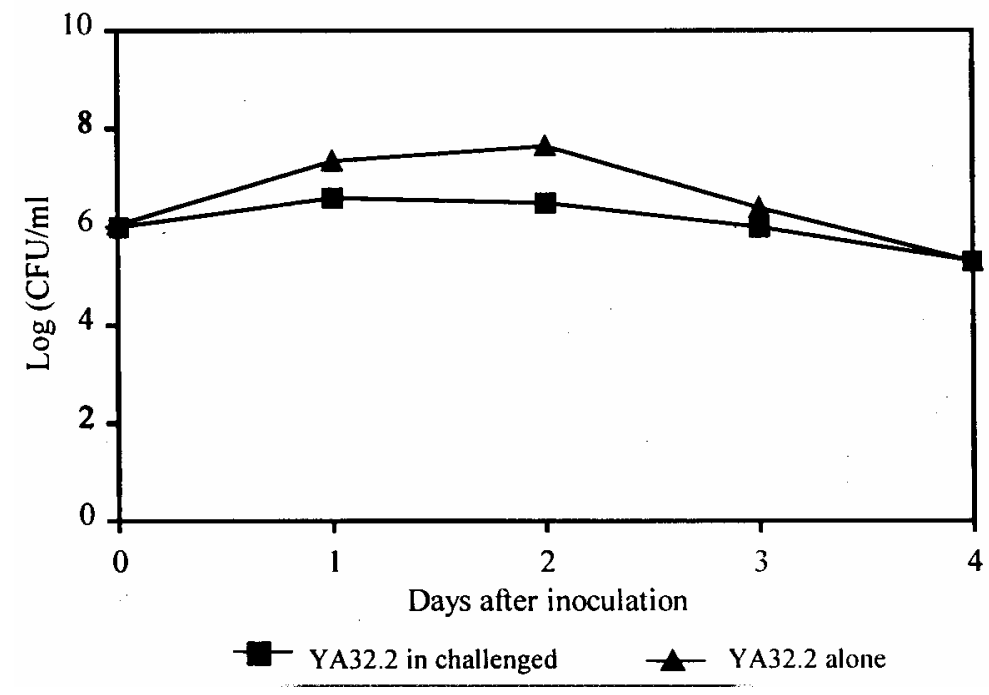

Figure 3. Comparison between bacterial cell count of YA32.2 when challenged or when inoculated alone 
BIOTROPIA NO. 18, 2002
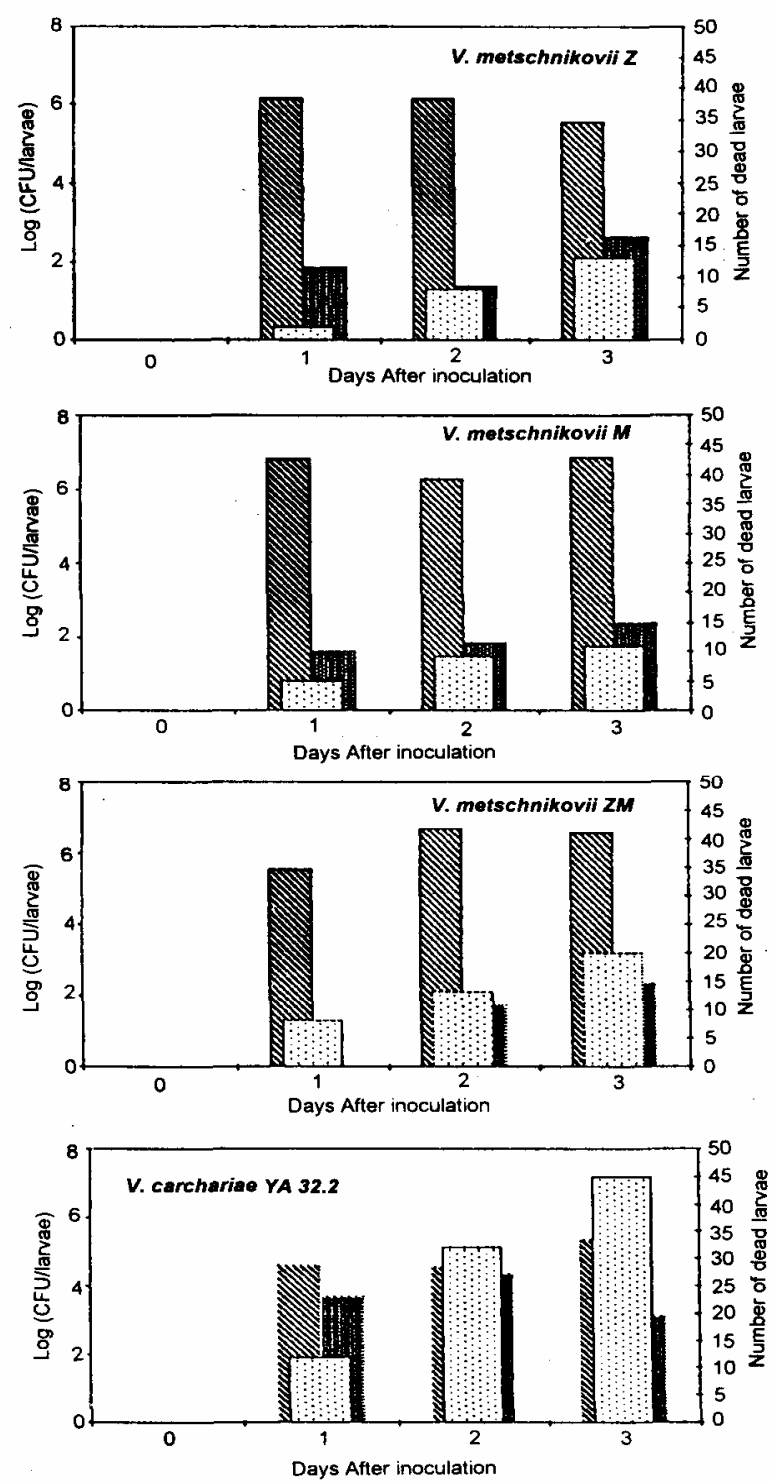

Cell count on TCBS: W. Cell count on TCBS+Rf D Dead larvae

Figure 4. Correlation between the number of dead larvae and YA32.2 adherence in a challenge test experiment 
Adherence and pathogenecity assay of Vibrio harveyi - Yusminah Hala et ill.

\section{DISCUSSION}

Fatty acid profile analyses indicated that isolates YA32.2 and YA31.4 were $V$. carchariae. The results indicated that VHA media which was supposedly selective for $V$. harveyi (Harris et al. 1996) actually could also support the growth of $V$. carchariae, although DNA-DNA hybridization analysis suggested that $V$. carchariae is a junior synonym for $V$. harveyi (Baumann et al. 1994). In addition, ribotyping of $V$. harveyi and $V$. carchariae indicates very similar DNA banding patterns (Pedersen et al. 1998). Physiology and genetic similarity might explain the ability $V$. carchariae to grow on VHA media that was originally designed as a selective media for $V$. harveyi.

One of the physiological characteristics of $V$. carchariae is its capability to hydrolyze urea $\left(\mathrm{UH}^{+}\right)$. Other reports indicated that brown shark (from where the original name of $V$. carchariae was derived) excreted urea for osmoregulation. It was suggested, therefore, that the adherence of $V$. carchariae to shark was due to urea-urease linkage (Bertone et al. 1996). Meanwhile, urea hydrolyzing activity was reported as an indication of potential pathogenicity of $V$. parahaemolyticus (Kays-ner et al. 1994). In V. parahaemolitycus, $\mathrm{UH}^{+}$is related to hemolysin production, which is a virulence factor of Vibrio (Osawa et al. 1996). The result of our study indicated that YA32.2, P1B and HB3 were $\mathrm{UH}^{+}$, and two of them (i.e. P1B and YA32.2) were isolated from the dead shrimp larvae. However, the shrimps were reported to excrete ammonia, instead of urea (Baticados 1988). Therefore, the adherence of $V$. harveyi to shrimp might not be mediated by urea-urease linkage.

Three isolates used in this research demonstrated similar sensitivity to the test antibiotics. They were resistant to ampicillin and kanamicin but sensitive to tetracycline, gentamicin and rifampicin. Vibrio carchariae isolated from shark skin ulcer was sensitive to tetracycline and resistant to piperacillin and carbenicillin (Bertone et al. 1996). Vibrio harveyi which was the causal agent for mass mortality of shrimp larvae in India, was sensitive to tetracycline but resistant to erythromycin. On the other hand, $V$. harveyi generally showed similar sensitivity to gentamicin (Austin et al. 1981) and rifampicin (Tjahyadi et al. 1994). This study indicated that $V$. harveyi P1B and HB3 and $V$. carchariae YA32.2 were sensitive to tetracycline, gentamicin and rifampicin. This result showed that $V$. harveyi isolated from anywhere has similarity in sensitivity to tetracycline, gentamicin and rifampicin.

Bacterial cell count of $V$. harveyi Rf* in larval-rearing water showed a different number from that of Vibrio sp which occurred naturally in larval rearing water. The difference indicated the-number of Vibrio sp originally colonized shrimp larvae. These Vibrio sp yielded green colonies which could not be distinguished from green colony of $V$. harveyi $\mathrm{Rf}^{*}$ in rearing water. Therefore, it is necessary to introduce molecular marker to distinguish the green colonies of Vibrio Rt* from the green colonies bf wi'd type Vibrio. 
P1B, HB3 and YA32.2 were sensitive to Rf. Therefore, in this experiment, we used Rf* as molecular marker to distinguish these three strains from the other $V$. harveyi isolates which occurred naturally in the shrimp larvae or larval rearing water. Vibrio harveyi Rf* mutants showed similar growth patterns to that of the wild type strain. This result indicated that the survival of $V$. harveyi $\mathrm{Rf}^{*}$ was similar to the wild type, and $\mathrm{Rf}^{*}$ character was stable even when it was kept in larval-rearing water.

Although the cell densities of each Vibrio $\mathrm{Rf}^{1} *$ in larval-rearing water were similar at approximately $10^{7} \mathrm{CFU} / \mathrm{ml}$ (Fig. 1), larval mortality in response to the three Rf* strains was different. The fastest and the highest larval mortality was due to YA32.2 inoculation which could be detected as early as one day after coin-oculation time. Larval mortality due to inoculation with P1B was detected after two days of coinoculation although the number of the dead larvae which resulted from those treatments was relatively similar. Probably, the two strains were potential pathogens because they were isolated from dead shrimp larvae. Similarly observed mortality was found when shrimp larvae were inoculated with similar density of $V$. campbellilike bacterium (Hameed 1995). Our study showed that HB3 was not pathogenic. Larval mortality in HB3 inoculation jar maybe due to the high density of Vibrio. Nonpathogenic or very weak pathogenicity of HB3 might be the reflection of its habitat where HB3 was originally obtained from pristine sea water in Southern Coast of Java Island.

Isolate YA32.2 was then selected for challenge test due to its potential pathogenicity. Vibrio metschnikovii as a challenge strain is a Vibrio species which usually adheres and colonizes shrimp larvae until the stages of post-larval stage. We assumed the strains of $V$. metschnikovii are not pathogen because they do not produce virulence factors (Widanarni 1999). Austin et al. (1995) used V. alginolyticus as a probiotic strain for $A$. salmonicida, $V$. anguillarum and $V$. ordalii. Our results indicated that $V$. metschnikovii $\mathrm{Z}$ or $\mathrm{M}$ could significantly reduce the growth and adherence of YA32.2 in shrimp larvae and significantly reduce larval mortality. This result demonstrated potential application of the adherence assay to screen for potential prdbiotics or biocontrol bacteria in shrimp hatcheries.

\section{ACKNOWLEDGMENT}

This work was funded by grants from Riset Unggulan Kemitraan (RUK), Indonesia, and International Foundation for Science (IFS, A/2207-2), Sweden, to Antonius Suwanto. 
Adherence and pathogenecity assay of Vibrio harveyi - Yusminah Hala et al.

\section{REFERENCES}

Anonymous. 1999. Aquaculture production statistics 1988-1997. FAO Fisheries Circular No 815, Revision 11. FAO, Roma.

Austin B., D.A. Morgan and D.J. Alderman. 1981. Comparison of antimicrobial agents for control of vibriosis in marine fish. Aquaculture, 26:1-12.

Austin, B. L.F., P.A. Stucken, W. Robertson, I. Effendi and D.R.W. Griffith. 1995. A probiotic strain of Vibrio alginolyticus effective in reducing diseases caused by Aeronumas salmonicida. Vibrio anguillarum and Vibrio ordalii.J. Fish Diseases. 18:93-96.

Baticados, M.C.L., 1988. Biology and culture of Penaeus numodon. Brackishwater Aquaculture Information System. Aquaculture Dept. SEAFD. Philippines, p: 144-149.

Baumann, P..A.L. Furniss and J.V. Lee. 1994. Facultative Anaerobic gram negative rods. In J.G. Holt, N.R. Krieg, P.H.A. Sneath, J.T.Staley, and S.T.Wilkins (eds.).Bergey s Manual of Determinatif Bacteriology. Ninth Edition. The William and Wilkins, Baltimore, Maryland, US A, p. 175-289.

Bertone, S., C. Gili, A. Moizo and L. Calegari. 1996. Vibrio carchariae associated with a chronic skin ulcer on a shark, Carcharhinus plumbeus (Nardo). J. Fish Dis. 19:429-434.

Eisenstadt, E., B.C. Carlton and B.J. Brown. 1994. Gene mutation. In: P. Gerhardt, R.G.E. Murray, W.A. Wood, N.R. Krieg. Methods for general and molecular bacteriology. American Society for Microbiology, p.297-316.

Grimes, D.J., J. Stemmler, H. Hada, E.B. May.D. Maneval, P.M. Hetrick, R.T. Jones, M.Stoskopf and R.R. Colwell. 1984. Vibrio spesies associated with mortality of sharks held in captivity. Microb. Ecol. 10:271-282.

Hameed, A.S.S. 1993. A study of the aerobic heterotrophc bacterial flora of hatchery-reared eggs, larvae and post larvae of Penaeus indicus. Aqua. 117:195-204.

Hameed, A.S.S. 1995. Susceptibility of three Penaeus sp to Vibrio campbelli-like bacterium. J. World Aqua. Soc. 26:315-319.

Harris, L., L. Owens and S. Smith. 1996. A selective and differential medium for Vibrio harveyi. Appl. Environ. Microbiol. 62:3548-3550.

Karunasagar, I., R. Pai, G.R. Malathi and I. Karunasagar. 1994. Mass mortality of Penaeus numodon larvae due to antibiotic-resistant Vibrio harveyi infection. Aquaculture 128:203-209.

Kaysner, C., C. Abeyata, Jr., P.A. Trost, J.H. Wetherington, K.C. Jinneman, W.E. Hill and M.M. Wekel. 1994. Urea hidrolysis can predict the potential pathogenicity of Vibrio parahaemolyticus strains isolated in the Pacific Northwest. Appl. Environ. Microbiol. 60:3020-3022.

Lavilla-Pitogo, C.R., M.C.L. Baticados, E.R. Cruz-Lacierda and L.D. de la Pena. 1990. Occurrence of luminous bacterial diseases of Penaeus numodon larvae in the Philippines. Aquaculture 91:1-13.

Lavilla-Pitogo, C.R., L.J. Albright, M.G. Paner and N.A. Sunaz. 1992. Studies on the sources of luminescent Vibrio harveyi in Penaeus monodon hatcheries. In: M. Shariff, R.P. Subasinghe, J.R. 
BIOTROPIA NO. 18, 2002

Arthur (eds). Diseases in Asian Aquaculture Fish Health Section. Asian Fish Society, Manila, Philippines, p:157-164.

Lavilla-Pitogo. C.R., E.M. Leano and M.G. Paner. 1998. Mortalities of pond-cultured juvenile shrimp, Penaeus numodon, associated with dominance of luminescent Vibrios in the rearing environment. Aquaculture.

Miller, L.T. 1982. Single derivatization method for routine analysis of bacterial whole-cell fatty acid methyl ester, including hydroxy acids. J. of Clin. Microbiol. 16,584-586.

Osawa, R., T. Okitsu, H. Morozumi and S. Yamai. 1996. Occurrence of urease positif Vibrio pamhaemolyticus in Kanagawa Japan with specific reference to presence of thermostable direct homolysin (TDH) and the TDH- related hemolysingenes. Appl. Environ. Microbiol. 62:725-727.

Pedersen, K., L. Verdonck, B. Austin, D.A. Austin, A.R. Blanch, P.A.D. Grimont, J. Jofre, S. Koblavi, J.L. Larsen, T. Tiainen, M.Vigneulle and J. Swings. 1998. Taxonomic evidence that Vibrato carchariae Grimes et al. 1985 is a junior synonym of Vibrato harveyi (Johnson and Shunk 1936) Baumann et al. 1981. Int. J. Syst. Bacteriol. 48:749-758.

Ruangpan, L. 1998. Luminous bacteria associated with shrimp mortality. In T.W. Flegel (ed), Advances in shrimp biotechnology. National Center for Genetic Engineering and Biotechnology, Bangkok, Thailand, p.206-211.

Salmond, G.P.C., B.W. Bycroft, G.S.A.B. Stewart and P. William. 1995. The bacterial enigma: cracking the code of cell-cell communication. Mol. Microbiol. 16:615-624.

Salyers, A.A. and D.D. Whitt. 1994. Bacterial pathogenesis, A molecular Approach. ASM Press. Washington D.C, p: 30-46.

Sunaryanto, A. and A. Mariam. 1986. Occurence of pathogenic bacteria causing luminescence in penaeid larva in Indonesian hatcheries. Bull. Brackishwater Aqua. Dev. Cent., 8:64-70.

Suwanto, A., M. Yuhana, E. Herawaty, and S.L. Angka. 1998. Genetic diversity of luminous Vibrio isolated from shrimp larvae. In Flegel, T.W. (ed) advances in shrimp biotechnology. National center for genetic engineering and biotechnology, Bangkok, p:217-224.

Teo, J.W.P., A. Suwanto, and C.L. Poh. 2000. Novel P-lactamase genes from two environmental isolates of Vibrio harveyi Antimicrob. Agents Chemother. 44: 1309-1314.

Tjahjadi, M.R., S.L. Angka and A. Suwanto. 1994. Isolation and evaluation of marine bacteria for biocontrol of luminous bacterial diseases in tiger shrimp larvae (Penaeus numodon. Fab.). As. Pac. J. Mol. Biol. Biotechnol. 2:347-352.

Widanarni and A. Suwanto, 2000. Genetic diversity of ampicilin-resistant Vibrio isolated from various stages of tiger shrimp larvae development. Biotropia. 15:36-47. 